\title{
The Discourse of Herrschaft as the Practice of Herrschaft in the Fifth Century ${ }^{1}$
}

\author{
Patrick J. Geary*
}

This essay examines the spectrum of political action and dominance from Constantinople to the frontiers of Noricum and Gaul at the end of the fifth century by comparing the lives of Zeno the Isurian, Theoderic the Great, Severinus of Noricum and Genovefa of Paris.

Keywords: Herrschaft, ethnicity, Zeno, Theoderic, Severinus, Genovefa

Max Weber famously defined Herrschaft as »die Möglichkeit, den eigenen Willen dem Verhalten anderer aufzuzwingen, " and further distinguished on the one hand "die Herrschaft kraft Interessenkonstellation, « and on the other »die Herrschaft kraft Autorität. « One way to compare the nature of power from the center of the late Roman Empire to its periphery in the last half of the fifth century is to take Weber's two »ideal types " of Herrschaft as a point of departure, even if, as he recognized, boundaries between the two are fluid. They are, after all, only models, but as George Box famously observed, »essentially, all models are wrong, but some are useful. $\aleph^{3}$ Moreover, the discourses within which the practice of Herrschaft is presented and grounded is anything but transparent: tropes and genres both provide a way into understanding the exercise of power but can also obscure, for cultural reasons, this exercise. Europe in the fifth century experiences a spectrum of formal and informal modes of Herrschaft, from long-established imperial authority to ad-hoc moments of what seem to correspond to Weberian charismatic Herrschaft. Weber's models are wrong when considering Herrschaft in its myriad manifestations in the fifth century, but they are indeed useful.

In order to explore the varieties of Herrschaft, which is often translated as "dominance» in English, ${ }^{4}$ this essay will consider how four very different figures came to exercise a power that made it possible for them to impose their own will upon the behavior of their contemporaries. Drawing primarily on recent reappraisals of these individuals and the sources by which we know them, we will see how the neat categories of domination by virtue of a constellation of interests and domination and by virtue of authority were intimately bound together; but also how impossible it is to distinguish between Weber's further distinctions among patriarchal, charismatic, and bureaucratic dominance. Finally, we will also see that the distinction between practice and discourse is equally problematic.

* Correspondence Details: Professor Patrick J. Geary, School of Historical Studies, Institute for Advanced Study, Einstein Drive, Princeton NJ 08540, email: geary@ias.edu.

1 A preliminary version of this paper was presented at the Alexander von Humboldt Foundation's 4. Bonner Humboldt-Preisträger-Forum »Herrschaft in der Antike - Praktiken und Diskurse« in Bonn, October 8, 2014.

2 Weber, Wirtschaft und Gesellschaft, 128.

3 Box and Draper, Empirical Model Building, 424.

4 Weber, Economy and Society. 
The lives of our examples, an Isaurian soldier named Tarasis (c. 425-9 April 491) who became the Emperor Zeno; ${ }^{5}$ the Gothic general Theoderic (454-526) who came to hold virtually the same, if unnamed office in the West; ${ }^{6}$ the vir dei Severinus (c. 410-8 January 482) active at the end of imperial presence in the provinces of Noricum and Raetia; ${ }^{7}$ and the virgo sacrata Genovefa (ca. 420-ca. 502) ${ }^{8}$ span a fairly narrow but significant chronological spectrum - essentially from the middle to the end of the fifth century. ${ }^{9}$ They represent however a wide range of human dominance, from the Roman Emperor to a relatively minor provincial woman. They lived, as goes the Chinese curse, »in interesting times. « Severinus was probably born around the year of the sack of Rome by Alaric; they all saw the violence of civil war both in the east and west of the Empire and had their lives fundamentally affected by the violence and threat posed by Attila and his Huns at mid-century. All lived through the deposition of Romulus Augustulus in 476, although this may or may not have seemed as momentous to them as it came to appear to subsequent generations. And by the time of the deaths of Genovefa ca. 502 and especially Theoderic in 526, the world of Late Antiquity was fundamentally different from that in which each was born: the East had endured but survived major crises that might have ended its existence; the West saw the definitive end, if not of Roman culture, then certainly of the Empire as a dominant political factor.

Two of these individuals ultimately assumed the reins of the bureaucratic apparatus of Empire, one in the East, one in the West; two struggled without office, official sanction, or indeed, in the case of Genovefa, without the possibility of gendered, patriarchal authority on the edges of a crumbling Empire. Each can be perceived only through a highly elaborated discourse that in part may obscure their rise to dominance in their individual spheres, but rather than retreating into the solipsism of post-structural ideology, these very discourses can be understood as part of what constituted their ability to impose their wills on their contemporaries.

Each of these figures, too, has been the subject of enormous scholarly interest and debate concerning the ideological, cultural, and political matrices in which they achieved their power. One of the primary tropes to understand the power exercised in the fifth century has

5 The traditional characterization of Zeno that relies on his ethnic identity as Isaurian and the opposition between Goths, Isaurians, and Romans in the Byzantine court is found in such works as Brooks, The Emperor Zenon, and is continued by historians including Jones, The Later Roman Empire, 217-229. This ethnic interpretation is being reassessed and this essay relies on the reinterpretations of Croke, Dynasty and Ethnicity and Wood, Multiple Voices in Chronicle Sources.

6 The changing approaches to the study of Theoderic and Ostrogothic Italy are well summarized in Arnold, Theoderic and the Roman Imperial Restoration, 5-7. Traditional views of Theoderic as a barbarian ruler such as that still present in Ward-Perkins, The Fall of Rome and the End of Civilization, are generally much more nuanced in the past decades including Burns, Theoderic the Great and the Concepts of Power; Burns, A History of the Ostrogoths; Heather, Theoderic, King of the Goths; Heather, The Goths; Wolfram, History of the Goths, and many of the essays in Teoderico il Grande e I Goti d'Italia.

7 Friedrich Lotter's Severinus von Noricum, the most important studies on Severinus and his hagiographer Eugippius have appeared in Pohl and Diesenberger, Eugippius und Severin. See also Hammer, >The Example of the Saints؛.

8 The fundamental studies of Genofeva are Heinzelmann, Zum Stand der Genovefa-Forschung, and Heinzelmann and Poulin, Les vies anciennes de sainte Geneviève de Paris. On the cult of Genovefa see also Hartmann-Petersen, Genovefa von Paris.

9 General surveys of the fifth century include Jones, The Later Roman Empire; Demandt, Die Spätantike; Cameron, The Mediterranean World in Late Antiquity; Drinkwater and Elton, Fifth-Century Gaul: A Crisis of Identity?; and Halsall, Barbarian Migrations and the Roman West. 
been ethnicity. ${ }^{10}$ Within the Empire as without, the ethnic background of individuals and parties has been seen as a major explanatory trope in political solidarities and the exercise of authority. Certainly the rise of Tarasis/Zeno, has traditionally been understood primarily in ethnic terms: Tarasis was after all an Isaurian, a population known for its military valor and that had long played an important part in the Imperial army. ${ }^{11}$ His rise in the court of Leo took place at the expense of the Roman general Aspar and his Thracian Gothic allies. Indeed, this is how the events were portrayed in the abridgment made by Photius of the lost account of Candidus, secretary to the highest ranking Roman officers in Isauria under Leo and Zeno, and the assumption that Leo sought to counterbalance Gothic power in his court by supporting another ethnic group, the Isaurians, has been long a part of the master narrative of the fifth century imperial history. ${ }^{12}$

Theoderic, of course, was famously a Goth, a member of the Amal family that claimed fifteen generations of rule over his people. ${ }^{13}$ He spent his youth as a pampered hostage in Constantinople, during the reign of Leo during the years of Gothic influence at the imperial court, and his return to the Goths may have followed and resulted from the murder of Aspar who was finally ambushed and murdered in 471 on Leo's orders. Within eight years he was leading a Gothic army reputed to be 10,000 strong on Constantinople. Then, after years of complex fighting, maneuvering, alliances and betrayals in Thrace, Theoderic turned his army toward Italy with the blessing of Zeno, destroyed the strong man Odoacer, and created his Ostrogothic kingdom.

If the traditional views of Zeno and Theoderic place an emphasis on their ethnic background to explain the source of their power, the situation is less clear with our other two examples, Severinus and Genovefa. One might assume that the hagiographical conventions that structured our primary sources on these two individuals intentionally edit out the ethnic or social foundations of their authority. The regional or ethnic origins of Severinus are unknown. According to his biographer Eugippius, when Primenius, an Italian priest who had sought refuge with Severinus, asked him about his origins, Severinus refused to say, asking rather his interlocutor what use it was for a servant of God to boast of his place of origin or his ethnicity (locus vel genus), when by keeping silent on these he could avoid vainglory. ${ }^{14}$ His terrestrial country of origin did not matter: what mattered was the celestial country he sought. How an unknown holy man could suddenly appear in Pannonia shortly after the collapse of the Hunnic empire and manage with apparent ease to command and counsel not only the remnants of Roman administration in the remaining towns along the Danube but the Arian kings of the Rugii as well, has confounded generations of scholars who assume that Severinus must have held high government office before retiring to the life of an ascetic. Friedrich

10 Of the vast, growing, and controversial literature on ethnicity and its role in late Antiquity see above all Pohl and Reimitz, Strategies of Distinction; the highly polemical attacks on Pohl in Gillett, On Barbarian Identity; and, in a wider and more intelligent perspective, Pohl, Gantner and Payne, Visions of Community.

11 On the ethnic approach to understanding these conflicts see Croke, Dynasty and Ethnicity, notes 147-148 as well as Elton, Illus and the Imperial Aristocracy under Zeno.

12 Candidus Isaurus, Fragmenta Historicorum Graecorum, 135-137. See Croke, Dynasty and Ethnicity, 161. See also Wood, Multiple Voices in Chronicle Sources, 302-303, who argues that Malalas's emphasis on ethnicity is part of the rhetoric that dichotomies as a competition between Goths and Romans what is actually intense political competition between leaders.

13 On Theoderic's construction of Amal geneaology see Wolfram, History of the Goths, 36-38; Heather, The Goths, 233; and Arnold, Theoderic and the Roman Imperial Restoration, 165-170.

14 Epistola Paschasii diaconi ad Eugippium presbyterum, Vita Severini, 3-4. 
Lotter even argued that he should be identified as Flavius Severinus, western consul in the year 461 , a suggestion now largely rejected. ${ }^{15}$ Whatever his background, he held no office in Noricum, refusing, according to Eugippius, election as bishop, even while continuing to exercise enormous authority over Romans and barbarians alike. For Eugippius, of course, the power of Severinus lies precisely in the title that he uses for him, and that Severinus seems to have preferred: vir Dei. What are we to make of this foundation of Herrschaft?

Genovefa, of course, was no vir, and her ability to exercise her own will to direct the behavior of her contemporaries in northern Gaul is even more remarkable. That is, of course, if she did so at all: Until the pioneering studies of Joseph-Claude Poulin and Martin Heinzelmann, it was generally thought that the Vita S. Genovefae was a late and generally fabulous creation. ${ }^{16}$ We now know that the earliest version was indeed written in the early sixth century and as such provides a close image of the saint as she was remembered in the decades immediately following her death. But who was this enigmatic figure? Assigning her to an ethnic group is much too simple: her name is Germanic, but her parents Severus and Geronica, bore Roman names. In terms of social prominence, they were sufficiently important in Nanterre that when Germanus of Auxerre passed through the region on his way to Brittan, he apparently spent time with them and their young daughter. But none of this explains how, after the death of her parents and her move to Paris, she would become someone who could organize the resistance of the Parisians during the invasion of Attila, effect the construction of the basilica of St. Denis, travel to neighboring towns in the style of a public official, negotiate the release of condemned prisoners with Frankish kings, and organize the delivery of the annota to a besieged Paris. Indeed, the Genovefa of the Vita seems, as Krusch ironically suggested, almost the "Mayor of Paris. ${ }^{17}$ What indeed is the source of her Herrschaft? Can we simply credit both Genovefa and Severinus with Weber's charismatic Herrschaft while Tarasis and Theoderic represent his patriarchal form?

Let us begin with Tarasis and the ethnic explanation of the events leading to the murder of Aspar and the rise of Zeno. If we could simply credit a Germanic vs. Isaurian power struggle in the court of Leo as generations of scholars have done, our job would be much simpler, and the resulting image would reify the long-held assumptions about the importance of ethnic identities in the struggles for power in the late Empire. However, as Erich Gruen has recently argued, ethnicity was a weak and ambiguous category for social categorization or political organization generally in Antiquity, ${ }^{18}$ and we would be well advised to take this into consideration when looking at the events in the court of Leo. One need not go so far as to discount ethnicity as a significant category altogether - the very instances that Gruen investigates indicates that it was an often invoked trope, even if it was seldom determinant, and thus held meaning in classical discourse. However one must be cautious about accepting ethnic identity as determinative in the creation of collations and in the exercise of dominance with-

15 Lotter, Severinus von Noricum. See Schwarcz, Severinus of Noricum between Fact and Fiction. For an early critique of such theses see Averil Cameron's review of Lotter.

16 Heinzelmann, Zum Stand der Genovefa-Forschung; Heinzelmann and Poulin, Les vies anciennes de sainte Geneviève, esp. 3-10. On the importance of Heinzelmann's and Poulin's work see Hartmann-Petersen, Genovefa von Paris, 17 and 50-54.

17 "Die Gott geweihte Jungfrau benimmt sich wie ein Mann und vollbringt Thaten, welche einem Maire von Paris zur Ehre gereichen würden, sich aber für ein Mädchen wenig schicken«, Krusch, Die Fälschung der Vita Genovefae, 21. See Heinzelmann, Zum Stand der Genovefa-Forschung, 546.

18 Gruen, Did Ancient Identity Depend on Ethnicity? 
in ancient societies. Brian Croke has done just this, overturning the way that we should understand the competition for power in Constantinople in the fifth century. ${ }^{19}$ Aspar may have been of Alan descent closely allied with important Gothic commanders, but as Croke has shown, his rise and long term exercise of power, including making possible Leo's own imperial ascendency, was not the result of his ethnic background but his effective role as a military commander and his judicious marriage policies, both for himself and his sons. It was military commands, held by Aspar himself and his son Ardaburius, that was the source of his power, not his ethnic background or the ethnicity of his wives and daughters-in-law. This is not to discount the importance of his close alliance and support with military factions, many of whom were Goths, but to reduce his authority simply to his Gothic support would be to ignore the importance of traditional power politics in the Imperial court. But if his ethnicity did not account for his rise, his religious adherence accounted for the glass ceiling that he and his family ultimately hit up against: his Arianism. Today we recognize that Arianism was not a unified religious movement: in late Antiquity - there were many Arianisms, and doctrinal differences separating orthodox and Arians were often minimal at best. ${ }^{20}$ Nevertheless in the courtly world of the fifth century, Arianism did matter greatly, and an Arian emperor could not possibly have gained "die Herrschaft kraft Interessenkonstellation." Aspar could hold to the de facto status of the most powerful man in the Empire, but he could never aspire to the de jure position, and thus was ultimately dependent on his own creation, the orthodox Leo. ${ }^{21}$ But of course Aspar sought the imperial throne, if not for himself then for his family. The weakness of his position and the significance of his confessional identity were demonstrated by the late agreement of his younger son Patricius to convert to orthodoxy upon his marriage to Leo's daughter as a means of securing the position of Caesar and presumptive successor to the aging Emperor. Confession, not ethnicity, was the major obstacle, and a formidable one, particularly with the rising importance of Tarasis.

That Tarasis was Isaurian was no more significant than Aspar's ethnic background and alliance. Many of Constantinople's military figures were also from Isauria, but this was no key to advancement and, as Croke has shown, Tarasis had had risen steadily in imperial service. Famously it was he who, in 465, produced documents that incriminated Aspar's son Ardaburius, who had been commanding in Antioch, in a conspiracy to enter an alliance with Persia. ${ }^{22}$ This was no accident: Tarasis had probably been one of Leo's agents sent to investigate Ardaburius's behavior, although his success in exposing Ardaburius and thus putting Aspar and his allies on the defensive led to a dramatic rise in his standing at court. ${ }^{23}$ In Croke's careful analysis, the fall of Aspar and the rise of Zeno have nothing to do with ethnicity or anti-Germanic sentiment in Constantinople and everything to do with good, old-fashioned dynastic politics. But there is one other aspect that Croke mentions but that needs further emphasis: Tarasis/Zeno could rise further than Aspar because, unlike the powerful patrician, he was orthodox. Zeno's rise, and the circumstances that made it possible, are best chronicled in the Life of Daniel the Stylite, which describes his service to Leo, his appointment as

Croke, Dynasty and Ethnicity.

See Hen, Conclusion: the Elusive Nature of an Orthodox Heresy.

On Arianism as a potential boundary see Wood, Multiple Voices in Chronicle Sources, 305-308.

Vita Danielis Stylitae 55. See Croke, Dynasty and Ethnicity, 160-168.

Croke, Dynasty and Ethnicity, 167. 
Domesticus, his marriage to Leo's daughter Ariadne, the birth of his son Leo, and following Emperor Leo's death, the succession of the infant and the appointment of Zeno as regent, and his succession as Emperor following his son's death. But more than chronicling Zeno's rise, the Vita emphasizes the alliance between the Stylite and Zeno, based on the latter's orthodoxy. As Daniel promised Leo when the Emperor sent Zeno on an military expedition, «as he has the holy Trinity and the invincible weapon of the Holy Cross on his side he will return unharmed. ${ }^{24}$ Zeno's orthodoxy, and the public support this assured him from the wonderworking stylite as well as from the elderly Leo, were central to the ideological foundation of his rule and his ability to achieve what Aspar and his clan could not.

Theoderic, his whole life an Arian, could never be Emperor. Or could he? It is too easy to see his rule in Italy as that of an Arian barbarian king supported by his Gothic army, a rule given but a veneer of Romanitas by his secretary Cassiodorus. His early career following his departure from Constantinople and his complex maneuvering in the Balkan provinces prior to reaching an agreement with Zeno that turned him toward Italy, is similar to the intrigues of other generals, Arian or orthodox, around the court. Once in Italy, however, Theoderic's situation changed dramatically. With the elimination of the western general Odoacer, Theoderic was prepared to fill a role desperately desired by the Italian elites, that of Emperor in the West. Of course his Gothic army, actually as heterogeneous as were all other fifth century armies, was essential to his power. But his ability to make himself the center of a constellation of the interests of western Roman elites was what made possible the consolidation of the more significant portions of the Western Empire for decades. The image that emerges from his correspondence penned by Cassiodorus is not just the projection of his learned secretary: it also corresponded to what Italian elites wanted desperately to believe. Thus, as Jonathan Arnold has recently argued, Theoderic was not just another barbarian commander but widely perceived as the restorer of the Empire in the West, a princeps Romanus whose martial abilities, embodied in his victorious army, completed the image of a Roman emperor, combining military valor (seen to have been lost in the effeminate East) with the civic virtues of an ideal Roman Augustus. ${ }^{25}$ The ideologically balanced and gendered language at Theodoric's court, as well as the panegyrics composed for him by Ennodius, drew on the whole repertoire of imperial ideology. As Procopius wrote, »in governing his own subjects he invested himself with all the qualities which appropriately belong to one who is by birth an emperor. $\aleph^{26}$ And yet, as Arian, he could continue to represent himself to his military as other than the effeminate rulers in the East. In this process, practice of power and discourse were inseparable: his ability to practice power was intimately connected to the discourses of imperial power as understood and earnestly sought in the West for over a century.

At the same time that Zeno and Theoderic were dominating their respective empires through the command of complex ideological and religious discourses backed by overwhelming force, dominance on the peripheries of the empire responded to different and less unitary rhythms. The reach of Roman domination did not mean much to the

26 Procopius, History of the Wars, 5, 1, 29. Procopius also claimed that Theodoric never assumed the dress (schematos) or name of emperor of the Romans, but as Arnold suggests, while he used other titles that harked back to the principate rather than that of Imperator, Procopius may have been mistaken about Theoderic's refusal to wear imperial dress and insignia. See Arnold, Theoderic and the Roman Imperial Restoration, chapter 4: The Imperial Image. 
beleaguered cities along the Danubian frontier, just as they were of little practical meaning to the threatened cities of northern Gaul. Here very different forms of Herrschaft, of domination, mattered, forms that are very difficult to perceive, but which we can perhaps glimpse in the extraordinary careers of Severinus and Genovefa, at least as mediated through the discourses woven by their biographers. It is perhaps best to consider first what these texts do not describe. There are no emperors, no principes Romanorum, in the worlds of Gaul and Noricum. Roman officers of any sort are notable primarily by their absence. In Noricum we still find Romani, and the rare tribunus commanding inadequate troops of frightened soldiers. ${ }^{27}$ Odoacer appears briefly, but at the beginning of his career, long before he is rex in Italy. ${ }^{28}$ An ecclesiastical hierarchy is dimly present, but while various bishops are mentioned, they are mostly individuals who are said later to become bishops: the bishops of Severinus's own day seem to be but shadows. ${ }^{29}$ Much more present are the kings of the Rugii and other barbarian tribes pressing on the Roman world, but they too are in fragile situations, as much under threat from their neighbors as are the Romans themselves.

Likewise in Genovefa's Gaul, religious and secular authorities are only dimly present: The bishops she encounters, from Germanus of Auxerre who blesses her on his journey to Britain, or Vilicius of Bourges who consecrates her, are not local to Paris. ${ }^{30}$ Indeed, no bishop of Paris is ever named and, apart from a few priests and deacons, Genovefa's interactions are exclusively with the laity. ${ }^{31}$ Nor are Roman officials in evidence: in the Vita Genovefae, just as in the Vita Severini, the only Roman official named is a single tribunus, and he is a supplicant to Genovefa. ${ }^{32}$ Very much present are barbarian kings, Attila who threatens Paris, and especially the Frankish kings Childeric and his son Clovis, with whom Genovefa negotiates and whom she outmaneuvers. Here she is like Severinus, who could cause the Alemannic king Gibuldus to tremble and secure the release of the king's Roman hostages. Genovefa's world, as constructed by her biographer, is one notably lacking in institutional authority: like Noricum, it is composed of communities of isolated towns, threatened by hostile forces, and largely left to themselves. They are in need of a defender, but no individual can command these hostile forces simply by authority. Severinus and Genovefa step into this vacuum.

True, both are from elite backgrounds, even if it is impossible to know them exactly: While certainly not the Consul Flavius Severinus, Severinus of Noricum came from a noble, senatorial background; he was versed in Roman law and in the niceties of diplomatic ceremonials; his Latin was that of an educated Italian. ${ }^{33}$ Genovefa, too, was from an elite background of Gallo-Roman aristocrats, she continued in her adulthood to control estates and servants, had

27 Vita Severini, 4.

28 Vita Severini, 7.

29 The tribunus Mamertinus is said to have later become a bishop, Vita Severini, 4; Paulinus, later bishop of Tiburnia, came to Severinus as a priest, Vita Severini, 25; Severinus orders bishop Constantinus of Lauriacum and his citizens to guard their city and thus they are able to defend against an attack. Vita Severini, 30. See Rosenberger, The Saint and the Bishop.

30 Germanus of Auxerre who blessed Genofeva as a child (Vita Genovefae 4) and Vilicus of Bourges who consecrates her are the only bishops with whom she has any direct contact (Vita Genovefae 6).

31 On Genofeva's interaction with local clergy and the singular absence of bishops see Bitel, Landscape with Two Saints, 64.

32 Vita Genovefae, 35.

33 Epistola Eugippii, 3. 
access to public transport, and had what we would call today "access « to the important people of her time. ${ }^{34}$ These backgrounds may indeed have been necessary preconditions to their ability to mobilize the communities through which they moved and to negotiate on their behalf with the barbarian kings who increasingly impinged on them, just as Theoderic's Gothic army was a necessary precondition to his dominance of Italy. However elite backgrounds were insufficient to explain their power in the rapidly shifting world of the imperial frontier. Here I think that we must take seriously the authority they derived, not from their inherited status, but from their twin positions as outsiders and as people of God, but people of God outside the disputed hierarchy of the age. Neither had substantial, existing networks in the communities where they were most active: Severinus simply appeared, and in spite of speculations to the contrary, there is no reason to assume a previous period of activity in Noricum. Genovefa arrived in Paris after the death of her parents and initially met determined opposition from within the city. Both became effective by offering the same radically different solution to the crises facing their adopted communities: faced with imminent destruction at the hands of barbarian armies, Severinus counseled prayer, fasting, and works of charity along with military tactics; Genovefa urged the same when Paris feared sacking by Attila ${ }^{35}$ but later, when the region is threatened by famine, she personally undertakes to transport of the annona. ${ }^{36}$ Traditional responses to external threat: reliance on Roman protection or simple flight, no longer offered security. Instead, these two wonder workers urged an internal response that combined locally organized resistance to external force with a transformation of the local community that was both spiritual and material. Whether this would have worked on Attila is questionable, and Paris's escape from destruction may simply be because it was never Attila's target. But certainly the evocation of a spiritual authority, along with the courage to face barbarian powers, be they Rugian or Frankish kings, and to accept their legitimacy even while demanding their protection, represented a very different approach.

And throughout their careers, neither figure sought to use the credit they received for their political interventions to create a more institutionalized form of power. Severinus, the vir dei, rejected the office of bishop and was neither fully a monk nor a hermit: ${ }^{37}$ as Ian Wood has argued, he existed on the margins of acceptable religious tradition, closer to the much despised girovagus than the kind of reputable abbot as would be demanded within a more settled world..$^{38}$ And Genovefa, the virgo sacrata, also eschewed the normal behavior of sanctified women who were expected to live as confined anchorites under religious authority, but rather traveled every bit as much as Severinus. Her role was closer to that of the de facto bishop of Paris, and yet as a woman there was no possibility of her assuming such a post. ${ }^{39}$ Nor did it matter: episcopal office didn't count for much on the edges of an empire. What counted was the ability of leaders to demonstrate their divine authority, then to turn this authority into action in their negotiations with the rising barbarian powers and the waning Roman communities of their day. Miracle working figures, who held no religious office, claimed no imperial authority, and adhered to no doctrinal faction, were best suited to this role.

Vita Genovefae, 34. See Heinzelmann and Poulin, 44-46 and 98 on her role in directing the collection and distribution of the annona.

35 Vita Genovefae, 10-12.

36 Vita Genovefae, 34.

37 Vita Severini, 9.

38 Wood, The Monastic Frontiers of the Vita Severini.

39 Again Wood makes the same comparison, Wood, The Monastic Frontiers of the Vita Severini, 49-50. 
In conclusion, we have seen the exercise of power at the two poles of the Roman world at the end of antiquity: in Constantinople, dominance continued to work through military force, dynastic politics, and institutional structures, but its limits were defined by the ability to conform to a community's vision of how that power should be exercised, a vision permeated by orthodox opposition to Arianism. In Italy, many of the same rules still applied - the elites still wanted a princeps, a Roman emperor who could embody both military and civic virtue, but the troubles of the first half of the century had left a much wider realm for manoeuver in confessional and institutional terms. On the frontier, the remnants of institutional, dynastic, and military power were perceived as inadequate to face the challenges of supporting barbarian power. Rather than imperial office holders supporting legitimate Roman lordship against illegitimate barbarian aggression, or even bishops defending orthodoxy against Arian barbarians, figures such as Severinus and Genovefa drew strength from their very marginality, but used this strength to win the respect and, for a while at least, the protection that they sought for their isolated and threatened communities. This, at least, is how contemporaries wished to understand them, this is how the discourse of power could be represented and operationalized at the end of the Ancient World. 


\section{References}

Arnold, Jonathan J., Theoderic and the Roman Imperial Restoration (Cambridge, 2014).

Bitel, Lisa M., Landscape with Two Saints: How Genovefa of Paris and Brigit of Kildare Built Christianity in Barbarian Europe (Oxford, 2009).

Box, George E. P. and Draper, Norman Richard, Empirical Model Building and Response Surfaces (New York, 1987).

Brooks, Ernest Walter, The Emperor Zenon and the Isurians, English Historical Review 8 (1893) 212-214.

Burns, Thomas S., A History of the Ostrogoths (Bloomington, 1984).

Burns, Thomas S., Theoderic the Great and the Concepts of Power in Late Antiquity, Acta Classica 25 (1982) 99-118.

Cameron, Averil, The Mediterranean World in Late Antiquity AD 395-60o (London, 1993).

Cameron, Averil, Severinus von Noricum by Friedrich Lotter. Reviewed in: The American Historical Review 83 (1978) 19.

Candidus Isaurus, Fragmenta Historicorum Graecorum, ed. Carolus Mueller V (Paris, 1851), 135-137.

Croke, Brian, Dynasty and Ethnicity: Emperor Leo I and the Eclipse of Aspar, Chiron 35 (2005) 148-203.

Demandt, Alexander, Die Spätantike: Römische Geschichte von Diocletian bis Justinian, 284-565 n. Chr. (Munich, 1989).

Drinkwater, John and Elton, Hugh, (eds.) Fifth-Century Gaul: A Crisis of Identity? (Cambridge, 1992).

Elton, Hugh, Illus and the Imperial Aristocracy under Zeno, Byzantion 70 (2000) 393-407.

Epistola Eugippii, Vita Severini, ed. Hermannus Sauppe, MGH AASS 1/1 (Berlin, 1877).

Gillett, Andrew (ed.), On Barbarian Identity: Critical Approaches to Ethnicity in the Early Middle Ages, Studies in the Early Middle Ages 4 (Turnhout, 2002).

Gruen, Erich, Did Ancient Identity Depend on Ethnicity? A Preliminary Probe, Phoenix, 67 (2013) 1-22.

Halsall, Guy, Barbarian Migrations and the Roman West 376-568 (Cambridge, 2007).

Hammer, Carl I., >The Example of the Saints`: Reading Eugippius' Account of Saint Severin, Classica et Mediaevalia 59 (2008) 155-186.

Hartmann-Petersen, Gönna, Genovefa von Paris: Person, Verehrung und Rezeption einer Heiligen des Frankenreiches: Eine paradigmatische Studie zur Heiligenverehrung im Frühmittelalter (Hamburg, 2007).

Heather, Peter, Theoderic, King of the Goths, Early Medieval Europe 4/2 (1995) 147-173.

Heather, Peter, The Goths (Oxford, 1996).

Heinzelmann, Martin and Poulin, Joseph-Claude, Les vies anciennes de sainte Geneviève de Paris. Études critiques (Paris, 1986).

Heinzelmann, Martin, Zum Stand der Genovefa-Forschung, Deutsches Archiv 41 (1985) 532-548.

Hen, Yitzhak, Conclusion: the Elusive Nature of an Orthodox Heresy. In: Guido M. Berndt and Roland Steinacher (eds.), Arianism: Roman Heresy and Barbarian Creed (Farnham, 2014) 311-315.

Jones, Arnold Hugh Martin, The Later Roman Empire 284-602, 2 vols. (Baltimore, 1986). 
Krusch, Bruno, Die Fälschung der Vita Genovefae, Neues Archiv 18 (1893) 8-50.

Lotter, Friedrich, Severinus von Noricum: Legende und historische Wirklichkeit: Untersuchungen zur Phase des Übergangs von spätantiken zu mittelalterlichen Denk- und Lebensformen, Monographien zur Geschichte des Mittelalters 12 (Stuttgart, 1976).

Pohl, Walter and Diesenberger, Max (eds.), Eugippius und Severin: Der Autor, der Text und der Heilige, Forschungen zur Geschichte des Mittelalters 2 (Vienna, 2001).

Pohl, Walter and Reimitz, Helmut (eds.), Strategies of Distinction: The Construction of Ethnic Communities, 300-80o, The Transformation of the Roman World 2 (Leiden, 1998).

Pohl, Walter, Gantner, Clemens and Payne, Richard (eds.), Visions of Community in the PostRoman World: the West, Byzantium and the Islamic World, 300-1100 (Farnham, 2012).

Procopius, History of the Wars, ed. by Henry Bronson Dewing, Loeb Classical Library, 5 vols. (Cambridge, 1914-1928).

Rosenberger, Veit, The Saint and the Bishop: Severinus of Noricum, in: Johan Leemans (ed.), Episcopal Elections in Late Antiquity (Berlin, 2011), 203-216.

Schwarcz, Andreas, Severinus of Noricum between Fact and Fiction, in: Pohl and Diesenberger, Eugippius und Severin, 25-31.

Teoderico il Grande e i Goti d'Italia: atti del XIII Congresso internazionale di studi sull'alto Medioevo (Spoleto, 1993).

Vita Danielis Stylitae, in: Hippolyte Delehaye (ed.), Les saints stylites, Subsidia hagiographica 14 (Brussels, 1923) 1-147.

Vita Genovefae virginis Parisiensis, ed. Bruno Krusch, MGH SSRM (Hannover, 1996) 204-238.

Vita Severini, ed. Hermann Sauppe, MGH AA 1/2 (Berlin, 1877).

Ward-Perkins, Bryan, The Fall of Rome and the End of Civilization (Oxford, 2005).

Weber, Max, Economy and Society: An Outline of Interpretative Sociology, ed. Guenther Roth and Claus Wittich (New York, 1968).

Weber, Max, Wirtschaft und Gesellschaft: Die Wirtschaft und die gesellschaftliche Ordnung und Mächte. Nachlass, Teilband 4: Herrschaft, ed. Edith Hanke and Thomas Kroll, Studienausgabe der Max-Weber-Gesamtausgabe (Tübingen, 2005).

Wolfram, Herwig, History of the Goths (Berkeley, 1988).

Wood, Ian, The Monastic Frontiers of the Vita Severini, in: Pohl and Diesenberger, Eugippius und Severin, 41-50.

Wood, Philip, Multiple Voices in Chronicle Sources: the Reign of Leo I (457-474) in Book Fourteen of Malalas, Journal of Late Antiquity 4/2 (2011) 298-314. 